\title{
A Linguistic Analysis of Friday Sermons of three Mosques in Yola Adamawa State Nigeria
}

\author{
Innocent E. Agu ${ }^{1}$, Evangelista C. Agu ${ }^{2}$, Abubakar T. Liman ${ }^{3}$ \\ ${ }^{1,2}$ Federal University Wukari, Nigeria \\ ejimofology@gmail.com \\ ${ }^{3}$ Adamawa State Polytechnic Yola, Nigeria
}

\begin{abstract}
This paper carried out a linguistic analysis of Friday sermons preached in three mosques in Yola, Adamawa state. It examined the lexico-syntactic structures of the language of these sermons. Purposive sampling technique was used to select six sermons from three different mosques covering the period of January to March 2015. The paper adopted the Lexical Functional Grammar (LFG) Theory of Bresnan and Kaplan (1970) to analyse the syntactic structures. This is a based grammar in theoretical linguistics. It posits two separate levels of syntactic structure, a phrase structure grammar representation of word order and constituency, and a representation of grammatical functions such as subject and object, similar to dependency grammar. It mainly focuses on syntax, including its relation with morphology and semantics. The paper found out that the sermons were structured in the conventional pattern of presenting Islamic sermons: the overall diction was simple. The sentences were varied. Simple, compound and complex sentences were all present in the sermons. Functionally, affirmative declarative sentences dominated the sermons. The paper concluded that the lexico-syntactic structure of the sermons aided the semantic import. Thus it recommended that religious preachers should endeavour to adopt simple words and sentences that would enable the adherents imbibe the positive tenets of their religious worships and practises.
\end{abstract}

Keywords- Linguistics, Analysis, Sermons and Mosques.

\section{INTRODUCTION}

This paper is aimed at carrying out a linguistic analysis of the texts of sermons preached at three different mosques in Yola, the capital city of Adamawa state in Nigeria. Halliday and Webster (2006) define language as a medium employed by human beings to aid communication. Language therefore becomes very effective as a communication tool when it is put into use within some contexts. Thus it is not experienced in isolation. It is situation or context-bound. The context, under which this analysis examines language, is therefore that of religious congregation. Here it is the Islamic religion.

In any Friday sermon the Imam, tries to convince the congregation and shares a message that relates to their religious obligations and day to day activities such that, at the end, it may lead to a change of opinion or action. Friday sermon texts are expected in some ways to make the listeners take heed and act upon what they have listened to (Liman, 2018)

Accordingly Liman (2018) posits that Friday sermon texts are mainly designed to call the worshippers to action. In other words the language of the sermons is fully loaded. Thus this study is aimed at analysing the content of such sermons with a view to unravelling its linguistic and scholarly imports. Because it is aimed at calling the worshippers to take action on their belief system, the language expectedly has the pragmatic force of persuasion which may captivate the interest of the listeners.

\section{PROBLEM OF THE STUDY}

The language of religious sermons has attracted the attention of researchers lately (Danladi, 2017 and Yerima, 2018,). A goodnumber of the scholars have concentrated on traditional and Christian religious practices. The few that examined the Islamic religion paid much attention to the themes of the sermons. The present researchers are poised to fill the gap provided by the apparent lack of interest on the language of Islamic sermons particularly in the North Eastern part of Nigeria.

\section{Aim /Objectives of the Study}

The general aim of the study is to carry outalinguistic analysis of the translated English versions of the Friday Islamic sermons from three mosques in Yola metropolis of Adamawa State of Nigeria.

The specific objectives of the study include to:

i. Identify the linguistically significant lexical items in the sermons

ii. Examine the syntactic structures of the selected sermons

Scope of the Study 
The study examined the linguistic features of selected English translations of Friday sermons in selected mosques in Yola, Adamawa state viz: Old GRA Mosque Yola, Airforce Base Mosque Yola and Federal College of Education Yola Mosque. In all a total of six sermons were purposively selected for the study, two from each mosque.

\section{REVIEW OF RELATED LITERATURE}

Wales (2001) worked on a dictionary of a wide range of linguistic phenomena in the field of interlanguage pragmatics (intonation, coherence devices, word order \& speech acts). He offered what he termed 'a representative overview of the current "state of the act" in cross-cultural pragmatics in general and pragmatics of inter language, English in particular. The study was far-reaching in terms of its scope but failed to narrow its analysis down to the study of the basic rudiments of the language of Islamic religious sermons. In this wise Wales (2001) fails to meet the yawning gap in the area of the study where the present study aims to fill the lacuna.

Another study (Bai and Shi, 2002) identified the multilingual style of sermons. These scholars examined the linguistic components of itinerant preachers whose sole aim was in getting a wider, cross-cultural audience and patronage. In other words the preachers of the various sermons had other motives in mind. They thus considered the fact that the album would not sell as much as it should if speakers of other Nigerianlanguages are not accommodated in the listenership, or the possibility of the preachers being classified as being ethno-linguistically biased.

Liman (2018) has also carried out a very similar study. The only major difference between the present study and that of Liman is in methodology. Liman used nine (9) texts while the present study is employing six (6). Above all, Liman used Halliday and Hasan's (1996) Cohesion in English as his analytical methodology while this study employs Bresnan and Kaplan's (1970) lexical Functional Grammar Theory.

In all, the present study posits that there has not been a very committed study on the area of the language of sermons from a strict linguistic perspective especially in the North Eastern part of Nigeria from where this study generates its data. Therefore it is hoped that the present study would provide the much needed anchor from where further studies would spring forth.

\section{Theoretical Framework}

For the purpose of this study, the analysis of data is anchored on the theoretical framework of Lexical functional grammar (LFG). This is a constraintbasedgrammar framework in theoretical linguistics. It posits two separate levels of syntactic structure, a phrase structure grammar representation of word order and constituency, and a representation of grammatical functions such as subject and object, similar to dependency grammar. The development of the theory was initiated by Joan Bresnan and Ronald Kaplan in the $1970 \mathrm{~s}$, in reaction to the theory of transformational grammar which was current in the late 1970s. It mainly focuses on syntax, including its relation with morphology and semantics, (Bresnan, 2001). There has been little LFG work on phonology (although ideas from optimality theory have recently been popular in LFG research).

LFG views language as being made up of multiple dimensions of structure. Each of these dimensions is represented as a distinct structure with its own rules, concepts, and form. The primary structures that have figured in LFG research are:

i. the representation of grammatical functions (fstructure).

ii. the structure of syntactic constituents (cstructure).

For example, in the sentence The old woman eats the apple, the c-structure analysis is that this is a sentence which is made up of two pieces, a noun phrase (NP) and a verb phrase (VP). The VP is itself made up of two pieces, a verb (V) and another NP. The NPs are also analysed into their parts. Finally, the bottom of the structure is composed of the words out of which the sentence is constructed, (Dalrymple, 2001).

The f-structure analysis, on the other hand, treats the sentence as being composed of attributes, which include features such as number and tense or functional units such as subject, predicate, or object.

The LFG conception of linguistic structure differs fromChomskyan theories, which have always involved separate levels of constituent structure representation mapped onto each other sequentially, via transformations. The LFG approach has had particular success with nonconfigurational languages, languages in which the relation between structure and function is less direct than it is in languages like English; for this reason LFG's adherents consider it a more plausible universal model of language, (Falk,2001).

Another feature of LFG is that grammatical-function changing operations likepassivizationare relations between word forms rather than sentences. This means that the active-passive relation, for example, is a relation between two types of verb rather than two trees. Active and passive verbs involve alternative mapping of the participants to grammatical functions, (Kroeger, 2004). Through the positing of productive processes in the lexicon and the separation of structure and function, LFG is able to account for syntactic patterns without the use of transformations defined over syntactic structure. For example, in a sentence like What did you see?, where 
what is understood as the object of see, transformational grammar puts what after see (the usual position for objects) in "deep structure", and then moves it. LFG analyzes what as having two functions: question-focus and object. It occupies the position associated in English with the question-focus function, and the constraints of the language allow it to take on the object function as well, Bresnan, Asudeh, Toivonen\& Wechsler, (2015).

A central goal in LFG research is to create a model of grammar with a depth which appeals to linguists while at the same time being efficiently parsable and having the rigidity of formalism which computational linguists require. Because of this, computational parsers have been developed and LFG has also been used as the theoretical basis of various machine translation tools, (Dalrymple, 2001).

The corpus: The table below shows the sources and dates of various sermons selected for analyses:

Table.1: Corpus Selection

\begin{tabular}{|cccc|}
\hline \multicolumn{1}{|l|}{ S/N Titlemonths Mosque } \\
\hline 1 & Text I: On choosing friends & January & OLD GRA, YOLA \\
2 & Text II: Tolerance and kindness to non & FebruaryAIR FORCE, YOLA \\
& Muslims & & OLD GRA, YOLA \\
3 & Text III:Good Ethics and their impact on society January & February & AIR FORCE, YOLA \\
4 & Text V: On thanking workers & January & F.C.E. YOLA \\
5 & Text VII: Roads to paradise & March & F.C.E YOLA \\
6 & Text IX: Taking good care of Children & &
\end{tabular}

\section{DATA PRESENTATION AND DISCUSSION}

\section{Text 1: On Choosing friends}

All the praise and thanks be to Allah, who has fostered mutual affection amongst His servants, making them intimate with each other. I bear witness there is no deity worthy of worship save him Alone, having no partners. I also certify that Muhammad is the servant of Allah and His Messenger. He was the best friend and companion, maythe peace and blessing of Allah be upon him,his family, his companions and all those who will follow them in righteousness till the Day of judgement.

The significant lexical items in the above text are shown in the table below. It must also be stressed here that Islamic sermons unlike those of their Christian counterparts are usually very brief. The entire worship hardly lasts twenty minutes because according to the rites of worship, the preparations (ablutions) are performed prior to the actual prayer session. The brief discussion on the lexical items comes after the table:

Table.2: On Choosing Friends

\begin{tabular}{|l|l|l|}
\hline Abstract nouns & Concrete nouns & Proper nouns \\
\hline Allah (perception) & Friends & Allah \\
Coexistence (perception) & Servants & Muhammed \\
Desire (perception) & Partners & Ibn Abbas \\
Deity (perception) & Companions & Luqman \\
Adversity (perception) & Messenger & Quran \\
Relation (social quality) & Individuals & \\
Bond (social quality) & Mothers & \\
Friendship (social quality) & Fathers & \\
Respect (social quality) & Houses & \\
Intimacy (social quality) & Brothers & \\
\hline
\end{tabular}

The above table is self-explanatory. The three columns isolated some of the different types of nouns seen in the text. The opening sentence is very remarkable. It opened with a kind adulation: 'All praise and thanks'. Here we witness a compound subject. But the irony is that the second noun 'thanks' is in its plural number while the first noun praise is singular. It becomes somewhat incongruent because the word praise can be pluralised as praises and then to be followed by thanks. That way the two would synchronise. One may also question the rationale for the inclusion of the determiner, the before the word praise in the first phrase. 
Again, there is a little form of inconsistency in the form of the pronouns and some other lexical items.For instance, the first letter in the word Allah is capitalised. This is understandable. Even from the above table the wordsuitably appears in the column for proper nouns. Moreover,being the supreme Deity of the Islamic religion, this is very suitable. The pronouns that refer to Him also have the first letters capitalised but this does not follow through in this text. The translators of the text must have erred grammatically because whereas in the first sentence, His servants refer to the servants of Allah, then in the clause I bear witness there is no deity worthy of worship save him Alone... .lettera in Alone is capitalised in place of the $h$ in Him. The same applies to other items in the text where capitalisation is omitted.

\section{Text 2: Tolerance and kindness to non-Muslims}

i. Thanks for Allah who honoured us with the tolerant religion of Is lam...

ii. Dear Muslims, Islam calls upon us to have good relations, sound understanding, and peaceful coexistence with all human beings irrespective of their faith, race or nationality.

iii. The history of Islam is full of great stories about cooperation among the three faiths.

Basically, text two comprises three sentences as abridged above. Some important lexical items (adjectives in all) capture the essence of this sermon. Thematically the sermon is anchored on tolerance. The following words (already underlined in the text) are of great semantic significance. They are:

Tolerant

good

sound

Peaceful

great

These adjectives coming before very important nouns: religion, relations, understanding, coexistence and stories actually foretell the positive image which the Islamic religion shows to the worshippers and even non adherents. It is believed that such positive attributes will make the religion attractive to all and sundry. To this effect, Liman (2018) posits:

Islam is a religion espousing the universal brotherhood of humanity. In fact, Is lam

Is lam was sent by Allah as a mercy, compassion and peace to mankind. There will be no stability without peaceful cooperation among Muslims and people from all over the world. The history of Islam is full of great stories about cooperation among the three faiths: Islam, Christianity and Judaism. It is our responsibility, dear Muslims, to shed light on the tolerance and moderation of our faith. (Paragraph 7)

Text 3: Good Ethics and their impact on society
The true believers keeps on performing acts of worship and avoids earning his living through any way that might displease Allah. He does so because he believes in and relies on his creator. What is more, his faith makes him rise above looking at what others have.

The first grammatical thing that hits the reader of this text is the lack of concord between some nouns and their verbs as in: believers...keeps; (believers) ...avoids. There is also a lack of concord between the noun believers and the pronoun pointing back to it his as in 'believers...avoids earning his living...'. This error has already been attributed to the medium of translation through which this text got to us. It is believed that this error does not exist in its original Arabic rendition. Thus we shall proceed with our analysis. From the first clause, it can be seen that Islam enjoins its adherents to be consistent in observing good work ethics both in worship and in secular means of livelihood. The progressive aspects of the verbs deployed and the present tenseforms inkeeps, avoids, does, believes, relies and makes go a long way towards impacting on the worshippers the state of currency which these virtues demand of them.

\section{Text 4: On thanking workers}

i. Truly, thanking people is a highly valued human virtue and moral decreed in Islam.

ii. Saying good words is one more way among many to show appreciation.

iii. $\quad$...expressing gratitude should be as much for numerous favours as for little.

iv. We need also to be kind to them through good words and gentle smile.

The structuring of the phrase highly valued human virtue is very catchy. The Imam who chooses the lexical items really knows how to attract and sustain the interests of the worshippers through his choice of words. The three lexical items: highly, valued andhuman end up qualifying the noun virtue. The virtue itself is another way of restating the subject of the sentence which was introduced at the beginning of the sentence throughthe gerundive phrase: '...thanking people'. In other words the sentence could have read: thanking people is a virtue. But then the Imam in an attempt to drive home the import of this virtue decided to include the phrase. So the complete sentence reads: Truly, thanking people is a highly valued human virtue decreed in Islam. The second and third sentences are just elaborations of the first sentence which actually serves as the topic sentence or the thes is of the entire sermon. The adjective phrases in the text really support this claim. Here are some examples: good words (repeated in iv), numerousfavours and gentle smile. 


\section{Text 5: Roads to paradise}

O Allah, forgive all the Muslims, men and women, living and dead, and make blessings follow us and them. May Allah have mercy on Sheikh Zayed and Sheikh Maktoum and all their brothers, the late UAE Sheikhs. O lord forgive and show mercy, you are Ever Merciful and there is no strength or power save with Allah, the High, the Great.

Text five is a peculiar kind of prayer. Its peculiarity is derived from the subject matter as shown in the captionRoads to paradise. It started with what is known as a vocative case in classical grammar: 'O Allah.' This is expected because the act of prayer is an implied dialogue between a person and his unseen listener, the supreme Deity. In this case the deity is Allah. The person saying the prayer started by pleading for forgiveness not just for himself alone but for '... all the Muslims, men and women, living and dead...'this is very comprehensive. It does appear that text six is a kind of Islamic Prayer Schema because immediately after the general prayer of forgiveness, he comes to the second stage of asking for blessings as in: 'make blessings follow us and them'. But the question that readily jumps to the reader's mind is: who are the them in the prayer? The positioning of the pronoun makes it easy for one to interpret them as pointing back to the phrase: all the Muslims, men and women, living and dead.

Another peculiarity in the prayer is in the introduction of the word us. The Imam prays thus: make blessings follow us and them. The word us makes it very inclusive. The Imam does not want to invoke Allah's blessings on the people while neglecting himself. Thus the use of the word us ensures that the blessings of Allah touches him too.

\section{Text 6: Taking good care of children}
i. Islam has laid solid foundations that ensure happiness for all mankind...
ii. Taking good care of children is a great responsibility.
iii. ...we avoid using violence, speaking obscene words...
iv. So for their good education, we need to strengthen in them our most beautiful values, good manners, noble norms and authentic traditions

The above text is replete with adjectives that seem to suggest the Imams love and interest in the lives of children. A tabulated presentation might make the meaning more obvious:

Table.3: list of adjectives and nouns in text 6

\begin{tabular}{|l|l|}
\hline Adjectives & Nouns \\
\hline
\end{tabular}

\begin{tabular}{|l|l|}
\hline Solid & Foundation \\
\hline Good & Care \\
\hline Great & Responsibility \\
\hline Obscene & Words \\
\hline Good & Education \\
\hline Most, beautiful & Values \\
\hline Good & Manners \\
\hline Noble & Norms \\
\hline Authentic & Traditions \\
\hline
\end{tabular}

In all, there are ten (10) adjectives qualifying nine (9) lexical items. The word values has two adjectives: most beautiful qualifying it. The implication of the above is that there is a great attachmentpaid to the children in Islam taking into consideration their roles as the future parents. Again, it is observed that only one adjective has a negative connotation, that is the word obscene. This is appropriate because the context of its utterance indicates that children should avoid it. It is one of those vices that children should avoid as they grow up. In the first sentence, the Imamuses a present perfective aspect of the verb...has laid. This indicates that it is something established not in the remote past but something still within their reach. This is appropriate semantically. The second sentence is very interesting syntactically. The interest stems from the fact the speaker uses gerund as the subject of the sentence as it takes the nominal position thus: taking good care of children is a great responsibility. This is very interesting as it brings elements of syntactic variety in the entire sentence structure of the sermons.

In the third sentence, the inclusiveness noticed in the previous text is repeated here through the use of the first person pronoun we in the sentence: ...so we avoid using violence, speaking obscene words.... Another implication here is that the Imam seems to have incorporated the adults in the task of moulding the characters of the children through the use of the pronoun we. The last sentence is very loaded with adjectives as noted earlier. The essence is to ensure that the children do not end up as societal failures. The norms and good traditions of the society must be inculcated into them at a very early stage of their lives and the mosque is one of the avenues for his transmission of worthwhile values.

\section{General linguistic Observations}

It is observed that the first text contains four sentences; three of them complex and only one is a simple sentence. The three complex sentences have asyndetic paratactic sentence structure marked off with commas and subordinating linkers with special graphitic notations. For instance the words denoting the supreme deity have their first letters capitalised. What defies grammatical 
interpretation is the shifting of the capitalisation to the word Alone instead of the pronoun him which refers to Allah. Ideally, the him should have been written as Him whileAlone should be written as alone. The only explanation one can hazard here is the translation error since the original text appeared in the Arabic language. This same text has two unique spellings in the proper noun column of table 2. The first is the word Luqman and the second Quran. All these are attributable to the Arabic etymology of the original text.

The second text has three sentences, two simple and one complex. The first sentence seems to have been culled from a more complex one due to the presence of the three elliptical dots. But what seems to be the most remarkable linguistic feature of this text is the presence of positive and attributive adjectives extolling the virtues of the Islamic religion as we see in the following phrases: tolerant religion, good relations, soundunderstanding, peacefulcoexistence and greatstories. These adjectives do not just adorn the text but they have specific religious functions to perform. They are inserted first to appeal to the adherents of the religion and also to appeal to nonMuslims to appreciate the virtue of Islam as a religion that tolerates and accommodates other shades of opinion. This can be seen in the last sentence of the text: The history of Islam is full of great stories about cooperation among the three faiths. The three faiths alluded to here are Christianity, Judaism and Islam itself.

Text three has three sentences in all. Only the last sentence could be said to be a simple sentence. The first two are a mixture of compound and complex sentences. This study has already commented on the lack of concord witnessed in the syntactic relation between some nouns and their verbs. The error was attributed to the translator and not necessarily to the Imam who preached the message. Beyond this, the present study is very much interested in the simplicity of the verbs employed by the text in conveying its message as in: keeps, avoids, does, believes, relies, makes and rise. The verbs are all in the present simple tense. This has one obvious message which is the ever presence of Allah who aids the adherents of the Is lamic religion in carrying out both their religious and social obligations with a view to achieving the full goal of the particular message in the text entitled: Good Ethics and their impact on the society.

The peculiar linguistic feature witnessed in text four, apart from the use of adjectives ( which is like a recurring decimal in the entire texts) is the use of the gerundives as witnessed in the following expressions: truly, thanking people is..., saying good words is...; expressing gratitude should be... there are four sentences in all and three use the gerunds in the nominative positions while the last sentence alone has a definite one-word subject $W e$. It is also worth noting that all four sentences are simple sentences.

Text five is a direct prayer to Allah as we see each of its three sentences beginning in a mood of supplication employing the lexical items: $O$ Allah...; May Allah...; $O$ lord... . In an attempt to further emphasize its semantic import of rendering prayers to Allah, the text goes further to use the following phrases: forgive all...; make blessings...; have mercy on...; O lord forgive and show mercy.... The text is again very interesting linguistically through the deployment of the word lord in the third sentence. Perhaps this is the first time the texts use that word in place of Allah. This study believes that the word is used as a mark of linguistic emphasis. In the end one notices that the interpretation of the entire text as a prayer is correct when it is noticed that certain individuals are mentioned by name as those that will receive Allah's forgiveness and mercy. Such names include: Sheikh Zayed and Sheikh Maktoum and all their brothers, the late UAE Sheikhs. This is in addition to the prayer earlier said for all in the first part of the text thus, $O$ Allah, forgive all the Muslims, men and women, living and dead, and make blessings follow us and them. We have already commented on the semantic inclusiveness of the pronoun $u s$ in this text.

Text six is morphologically loaded and much has been said about it both in the table made from it and the brief comments after the table.

\section{CONCLUSION}

It can be seen from the brief comments above that Is lamic sermons are usually very brief and to the point. It does not make unnecessarily long sentences. But the few sentences witnessed are mostly declarative or imperative. The lexical items employed by the preachers are not ambiguous in any way. The preachers have a way of saying exactly what they mean either by way of prayers or giving injunctions to Moslem faithful. The Linguistic theory employed for the analysis is also the one that is straight and simple devoid of any linguisticcomplexities. The Lexical Functional Grammar makes linguistic analysis very simple as it identifies lexical items and categorises themaccording to the functions they perform in the sentences either as C-or F-Structures. This is what the above study has done. Based on this, the study recommends that preachers of all religions should choose simple dictions and sentences devoid of any ambiguity even when they talk about other religious groups as we seen above. 


\section{REFERENCES}

[1] Bai, S. and Shi, A. (2002). A comparative Study of Figures of Speech between Chinese and English. Journal of Xinhou Teachers University, 70-71

[2] Bresnan, J. (2001). Lexical-Functional Syntax. London: Blackwell.

[3] Bresnan, J., Asudeh, A.,Toivonen, I., Wechsler\& S. (2015).Lexical Functional Syntax.2nd edition. London: Wiley Blackwell.

[4] Danes, F. (1974).'Functional Sentence Perspective and the organization of the text', in Papers on Functional Sentence Perspective (JanuaLinguarum, Ser. Minor, 147) ed. By F.Danes. The Hague: Mouton, 106http://dx.doi.org/10.1515/9783111676524.106

[5] Danladi, A.A. (2017). 'A Comparative Study of Pentcostal and Orthodox Sermons in Wukari Area of Taraba State.'Unpublished Project, Federal University Wukari

[6] Dalrymple, M. (2001).Lexical Functional Grammar.No. 42 in Syntax and Semantics Series. New York: Academic Press.

[7] Falk, Y. N. (2001). Lexical-Functional Grammar: An Introduction to Parallel Constraint-Based Syntax. CSLI.ISBN 1-57586-341-3

[8] Halliday, M.A.K. and Webster, J.(2006). Language and Linguistics. Victoria: Continuum International Publishing Group

[9] Kroeger, P. R. (2004). Analyzing Syntax: A LexicalFunctional Approach. Cambridge: Cambridge University Press. ISBN 9780521016544

[10] Liman, A.T. (2018).Linguistic Analysis of Friday Sermons of selected Mosques in Yola.Unpublished M.A Thesis, Modibbo Adama University of Technology Yola

[11] Wales, K. (2001). A Dictionary of Stylistics. Harlow: Longman Press

[12] Yerima, O. (2018). 'A Comparative Study of the Language of Catholic and Pentecostal Church Sermons', Unpublished Student's Project, Federal University Wukari 